Andrew James Kier

kier.4@buckeyemail.osu.edu

\title{
„Instruments of the Old Faith": Magical Words in Three Medieval South Slavic Healing Rites for Snakebite
}

ABSTRACT. Kier Andrew James, „Instruments of the Old Faith”: Magical Words in Three Medieval South Slavic Healing Rites for Snakebite. „Poznańskie Studia Slawistyczne” 3. Poznań 2012. Adam Mickiewicz University Press, pp. 75-87. ISBN 978-83-232-2473-0. ISSN 2084-3011.

The line between Orthodox Christianity and pagan/folk customs and beliefs in the fifteenth century Slavia Orthodoxa was not precisely drawn. The population called upon spiritual forces of all kinds, to heal illnesses and injuries. Though the official position of the Orthodox Christian Church was to condemn and suppress these pre-Christian beliefs, certain elements such as magical words were included in Church-sanctioned texts. The fifteenth-century South Slavic trebnik (Hilandar HM.SMS.378) is one example of such a text. In addition to its canonical material, it contains a healing rite for a snakebite, which blends Orthodox Christian elements and pre-Christian ones, utilizing magical words.

In this article, I examine Hilandar HM.SMS.378 - the magical words, the symbolism, and the cultural background - and compare it with two similar rites from a medieval South Slavic lječebnik ('book of healing') transcribed by V. Jagić in 1878. I also discuss the possibility that the three rites share a common origin.

Keywords: magical words, trebnik, lječebnik, non-canonical, Hilandar HM.SMS.378, preChristian, snakebite

\section{Introduction*}

The line between Christianity and pagan/folk customs and beliefs in the fifteenth century Slavia Orthodoxa was not drawn precisely. One result

* I would like to acknowledge and express my gratitude to the Hilandar monks for allowing the use of the Hilandar HM.SMS.378 manuscript, and to Dr. Predrag Matejić, Curator of the Hilandar Research Library, and M.A. „Pasha” Johnson, Assistant Curator, who provided access to the microforms of this manuscript. All translations throughout this article are mine. 
of this was that in matters related to health and disease, much of the population in these regions called upon spiritual forces of all types, that these forces might intercede against the injurious powers of the unknown (manifested in various illnesses and abnormal physical conditions) and expel them from the suffering patient. Throughout medieval Europe „the expectancy of a short life and perhaps more intimidating, the harsh and uncertain fate of the living caused contemporaries to hedge their cosmological bets. People exploited every available option, and those who accepted any new faith did not discard the instruments of the old"1. These, instruments of the old" incorporated elements from various belief systems layered upon one another, each having its own stock of rituals, prayers, incantations, and magical formulas for the protection of humans and animals from unforeseen illnesses, injuries, and other harmful events.

Peasants and nobility alike synthesized canonical Orthodox teachings with the customs their own ancestors had practiced in the generations before them - beliefs such as the magical properties of stone, earth, water, fire, and air, the ,primordial elements of the world" ${ }^{2}$. They petitioned these and other natural forces such as the weather and the seasons with ,the presupposition (...) that things in this world (...) had a will of their own and could be cajoled into behaving in a certain way"3. In addition, people understood health, human character traits, fortunes, and misfortunes which were a daily part of life as manifestations of an infinitely subtle interplay of otherworldly forces - both helpful and harmful - which had the ability to willfully penetrate the veil of the physical world, either by their own cunning or through human help or weakness.

That the persistence of older customs and beliefs was an ongoing irritation to medieval Orthodox Christianity (especially at the higher levels) is clear from abundant evidence documented by Church officials - evidence which, ironically, gives us much of our knowledge about the details of these pre-Christian practices. People from all walks of life recited zagovory

\footnotetext{
${ }^{1}$ W. Husband, „Godless Communists”. Atheism and Society in Soviet Russia, 19171932, Illinois 2000, p. 6.

${ }^{2}$ E. Levkievskaja, S. Tolstaja, Kamen, in: Slavjanskie drevnosti. Ėtnolingvističeskij slovar, ed. N. Tolstoj, Moskva 1995, vol. II, p. 448.

${ }^{3}$ E. Levin, Supplicatory Prayers as a Source for Popular Religious Culture in Muscovite Russia, in: Religion and Culture in Early Modern Russia and Ukraine, ed. S. Baron, N. Kollmann, Illinois 1997, p. 104.
} 
('charms, spells') for a variety of occasions despite warnings from religious authorities. However, ,the fact that zagovory were condemned by the Church does not mean that the clergy did not resort to them; indeed, being more likely to be literate than their parishioners, and to be called to the bedside of the sick, priests were often specified as being necessary for the reading of a zagovor" . Yet despite their readiness to tend to the physical health of their flock, officials often denounced the methods of these clergymen: ,In their Euchologia (...) the stupid village priests have false writings $(\ldots)$ and false healing Prayers for the Fevers and for infections and for sicknesses. And they write fever letters on prosphorae and on apples, because of sickness",

The fact that church officials themselves often allowed the inclusion of both Christian and pre-Christian elements in Church-sanctioned texts (though it is entirely possible that they could not always distinguish a clear line between the two) is evidenced by a fifteenth-century South Slavic ${ }^{6}$ trebnik (Hilandar HM.SMS.378) which contains an unusual rite for the healing of a snakebite victim. Located among the normal, canonical material, this rite opens with a curious group of words, and involves several ritual actions. In this article I will examine the rite's contents, with a focus on the magical words, and compare them with other words from two similar rites from a medieval South Slavic lječebnik transcribed by V. Jagić in 1878 in the journal „Starine"

\section{A Broad Palette of Beliefs}

As late as the fifteenth century, pre-Christian belief systems still held sway in various Slavic regions, especially in rural and isolated areas. „It would seem $(\ldots)$ that the new ideology made slow headway in (...) agri-

\footnotetext{
${ }^{4}$ W. Ryan, Bathhouse at Midnight: an Historical Survey of Magic and Divination in Russia, Pennsylvania 1999, p. 201.

${ }^{5}$ R. Mathieson, Magic in Slavia Orthodoxa: the Written Tradition, in: Byzantine Magic, ed. H. Maguire, Washington 1995, p. 163.

${ }^{6}$ The phonological and graphic features of Hilandar HM.SMS.378 place its origin within the region of the Serbian recension.

${ }^{7}$ Where I refer specifically to Hilandar HM.SMS.378, I have capitalized the word Trebnik. Where I refer nonspecifically to trebnik as a form, the word appears uncapitalized.
} 
cultural communities in conditions of relative mutual isolation and characterized by their conservatism, with the rhythm of their lives so closely intertwined (especially in the sphere of belief) with the natural rhythm of nature" ${ }^{\prime}$. Magical words and incantations persisted for generations after the older customs organized around them had disappeared.

It is likely that the content of the specific rites which I examine in this work had already undergone changes and revisions over the course of many centuries by the time they were finally written down. They were 'frozen', so to speak, at the particular moment at which they were committed to paper. Nonetheless it is possible (on a broader level) for traces of pre-Christian magical incantations to survive over time, aided by the perdurative power of oral recitation.

The common denominator in the medieval conceptualization of health and sickness was the belief that a state of illness occurred through the actions of harmful supernatural forces (demons, spirits, etc.) willfully invading an otherwise healthy person's body. Conversely, the healing of the body involved expelling these demons by summoning the assistance of spiritual powers. A person professing to be a Christian was expected to beseech only God, either directly or through the intercession of Jesus Christ or of a Christian saint. For a human being to attempt to cause a demon or spirit to leave a body by directly influencing or controlling supernatural forces was (and is) considered heretical. Church officials acknowledged that, although it was indeed possible for an ordinary human being to undertake this action, to do so was to create the possibility of further danger and harm. „The clergy itself did not doubt the existence of demons, but tried to forbid their cults" ". Through human actions, internal and external spiritual power could be set in motion. Internal powers are those which ,reside within the psyche of the agent - such as the evil eye, witchcraft, gifts of vision or prophecy" ${ }^{\prime 10}$. External powers are „external symbols on which the agent must consciously work; spells, blessings, curses, charms (...). These powers require actions by which spiritual power is discharged"11. The

${ }^{8}$ P. Barford, The Early Slavs: Culture and Society in Early Medieval Eastern Europe, New York 2001, p. 223.

${ }^{9}$ Ibidem, p. 224.

${ }^{10}$ M. Douglas, Purity and Danger: an Analysis of the Concepts of Pollution and Taboo, London 1966, p. 98.

${ }^{11}$ Ibidem. 
snakebite healing rite in the Trebnik represents the second type of dischargement of spiritual power, through a combination of words and ritual actions. Moreover, it is intended specifically for healing; performing this rite allowed an agent (most likely the parish priest) to harness or control certain supernatural powers in order to return a person to a normal state of health.

\section{Trebniki and lječebniki}

A trebnik (pl. trebniki) ${ }^{12}$ is an Orthodox Christian text containing various prayers and Rites (of Confession, Baptism, Marriage, etc.) for the members of a parish or diocese. The order and format of its contents vary; there is no single template which must be followed. Trebniki were written to fulfill the spiritual needs of an individual religious community, and were actively employed to this end. As it exists now, Hilandar HM.SMS.378 is a convolute consisting of two sections: the first (ff. 1-62) was written or copied between 1475 and 1500, while the second (ff. 63-345) dates from between 1400 and 1425 . The snakebite rite is found in the second section. The two other snakebite rites are from a medieval South Slavic lječebnik 'healer/healing book' - a generic collection of rites, prayers, and remedies for the treatment of various illnesses and conditions. It is important to note that lječebniki were neither associated with nor sanctioned by the Church; they were compiled strictly for private use. These texts, when tolerated by Orthodox clergy at all, probably occupied the fringes of acceptability in the eyes of Church officials.

\section{Canonical Prayers and Rites}

A typical canonical Orthodox Christian prayer was recited directly to God, for the purpose of either expressing gratitude to Him or of beseeching Him to directly manipulate earthly events, natural states, people, or things - for example, to ask for a bountiful grape harvest or a safe voyage on a ship. Hilandar HM.SMS.378 is made up of a multitude of prayers and

\footnotetext{
${ }^{12}$ In English it is usually referred to as 'Book of Needs', and in Greek as Euchologion 'prayer book'.
} 
rites for many occasions, the vast majority of which follow the expected Orthodox canonical form. A prayer (as opposed to a rite) is a verbal request made directly to God, while a rite is a set of actions to be carried out by an officiant. Prayers and rites often appear together, but not always. The Trebnik snakebite healing rite is identified in the MS by the term $m$ [o]l[i]tva 'prayer' rather than čins 'rite', although it does not contain an actual prayer. Many such non-canonical rites begin with instructions to assemble a list of ingredients, or to perform some act such as writing certain words on an object. The Trebnik rite includes both of these. In the following sections I will discuss some of the formal elements described above, which are found in the snakebite rites in the Trebnik and the lječebnik.

\section{Prayer Against a Snake (Hilandar HM.SMS.378, ff. $222 v-223$ )}

M[o]l[i]tva òt zmïe.

Xerufimb xirïe sifotafarafota. samamoilb manoilb. parakli[i]tusb. ili je béla ili črbvěna ili je črbna pročti sïju m[o]l[i]tvu. [3] ōot]če n[a]šb [3] i koi čl[ově] kb pově Ere nekoga zmïa ujela da kto xoštetb m[o]l[itvu] čisti sïju da imětb za skutb povědav[b]šago i postavitb vodu ne načetu ${ }^{13}$ u čaši i po končani m[o]l[i]tvy. nadb vodomb. Vbz[b]mětb vodu i procéditb skrozě skutb [3] $i$ das[tъ] ispiti povědav[b]šomu.

Prayer against a snake. Cherubim kyrie sifotafarafota; samamoilb, manoilb, paraklitusb. Whether [the snake] is white or red or is black, read this prayer three times [and] the Lord's Prayer three times. And whichever person made it known that someone was bitten by a snake, let whomever who will read this prayer take him who had witnessed [the snake] by the lappet ${ }^{14}$, and place fresh water ${ }^{15}$ into a cup. And after the end of the prayer over the water, take the water and filter it through the lappet three times, and give it to the person who had witnessed [the snake], to drink [it] up.

${ }^{13}$ In modern BCS, nenačet means 'uncut, whole'. The verb načeti, besides the meaning of 'bite into, cut into', can also mean 'tap', e.g. načeti bure 'tap a barrel'. M. Benson, B. Šljivić-Šimšić, Serbocroatian-English Dictionary, Philadelphia 1971, p. 337.

${ }^{14}$ The hem of a garment.

${ }^{15}$ Lit. 'unbegun water'. 


\subsection{Xerufimb, xirïe, and sifotafarafota}

The rite opens with six words which appear to be an incantation. Xerufimb (OCS xeruvimb, xerovimb) is a borrowing from Hebrew כרובים 'cherubim' - collectively, the biblical winged beings, ,statues of which were placed at the entrance to the Tabernacle and the Temple, symbolizing the presence of God"16. In the Garden of Eden they protected the tree of life ${ }^{17}$. The phoneme [f] in xerufimb is not native to Slavic, so the word in this guise was probably intended to sound as non-Slavic (and therefore exotic) as possible. The alternative form xeruvïmb appears in several other places throughout the Trebnik (ff. 188v, 193v et al.). The use of $\ddot{i}$ (in Slavic) between two consonants is unusual; normally it presupposes an adjacent vowel letter.

Xirïe is apparently a deformation of $\kappa v \rho l \varepsilon$ (Greek 'lord', voc. sg.), most commonly found in the phrase Kyrie eleison 'Lord have mercy'. The Greek word predates Christian worship, finding use ,in various forms of pagan worship including the imperial cult in which the emperor was called kyrios (lord)" ${ }^{\prime 18}$. It was adopted by early Christians as a term with which to address Christ. In Orthodox Slavic Christian contexts it is unusual to see kyrie without the word eleison, except as a title (kirb/kjurb) preceding the proper name of a bishop ${ }^{19}$.

The third word is sifotafarafota. Magic words appear in other medieval Slavic texts as well: „A prayer for heart disease in a trebnik (completely canonical otherwise) included instructions to write six words of power"20. They are „Elamъ. Selamъ. Vargotha. Tothathi. Thivva. Rasis”21. Certain words were believed to give an officiant the power to directly manipulate

${ }^{16}$ Old and the New Testaments of the Holy Bible, Revised Standard Version, Boston 1971, p. 7.

${ }^{17}$ „He drove out the man [Adam]; and at the east of the garden of Eden he placed the cherubim (...) to guard the way to the tree of life". Genesis 3,24, RSV.

18 „Definitions for Medieval Christian Liturgy: Kyrie eleison”, <http://www.yale.edu/ adhoc/research_resources/liturgy/d_kyrie.html> [date of access: 3.3.2006].

${ }^{19}$ I. Sreznevskij, Slovar' drevnerusskogo jazyka, reprint edition, vol. I, pt. 2, Moskva 1893-1912/1989, p. 1419.

${ }^{20}$ E. Levin, op. cit.

${ }^{21}$ Ibidem, p. 113, n. 37 
physical states, whether the words were uttered aloud or written down ${ }^{22}$. Alliteration and rhyming are typical features within magical formulas; a South Slavic prayer against tooth disease contains the highly alliterative formula dede udede vris... kadedesb udedesb ${ }^{23}$. With abracadabra-type words such as these, ,it is not always clear what they represent: secret writing, words from another language left untranslated, an imitation of words in some sacred language, or simply Slavic words distorted during transliteration from the protograph text" ${ }^{24}$. Some of these words were also elements within 'magic squares', or were palindromic.

Sifotafarafota is an alliteration probably intended to sound Greek. It could represent an entire phrase or just a single alliterative word. The nonSlavic [f] occurs three times in rapid succession. Two fota's are broken up with a fara in the middle. It is possible that sifotafarafota is a magical reversal; sifo spelled backwards is ofis (Greek 'snake'). The next element is arafat (the reversal of tafara). Aravat is mentioned in the pseudepigraphical Book of the Secrets of Enoch as a Hebrew name of God. During Enoch's visit to the seventh heaven (chapter 20), „fiery troops of great archangels" ${ }^{25}$, cherubim, seraphim, and various other ,many-eyed ones" reveal to him ,the Lord from afar, sitting on His very high throne (...) On the tenth heaven is God, in the Hebrew tongue he is called Aravat",26, which means 'father of creation'.

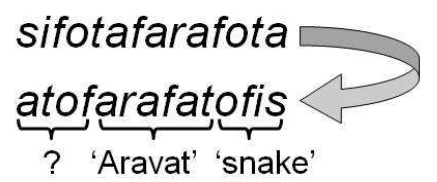

Fig. 1. Possible magical reversal of sifotafarafota in Hilandar HM.SMS.378

${ }^{22}$ One well-known example of this is the ancient form abracadabra, originally used in pre-Christian healing rites.

${ }^{23}$ V. Jagić, Opisi i izvodi iz nekoliko južnoslovinskih rukopisa, ,Starine” no. 10, 1878, p. 92.

${ }^{24}$ A. Toporkov, Zagovory v russkoj rukopisnoj tradicii XV-XIX vv.: Istorija, Simvolika, Poètika, Moskva 2005, p. 310.

${ }^{25}$ Charles uses two sources, both of South Slavic provenance, translated side-by-side. I cite here the more complete source, published by A. Popov in Transactions of the Historical and Archaeological Society of the University of Moscow, vol. III, Moskva 1880.

${ }^{26}$ Apocrypha and Pseudepigrapha of the Old Testament, ed. R. Charles, vol. II, Berkeley, California 2004, p. 441, col. A. 
The element atof (the reversal of fota) needs to be explained, if this sequence indeed represents a magical reversal.

An apotropaic incantation against snakebite is still used in eastern Herzegovina, according to Radenkovic ${ }^{27}$ : „Fata, fata / kissed some gold / with gold some gold." Fata in this instance may represent fata (Latin 'fate'), which could refer to the three Fates. The fotafarafota in the Trebnik could conceivably have this origin as well.

\subsection{Samamoilb, manoilb, and paraklitusb}

A possible source for the word samamoilb is Sammael ${ }^{28}$, one of the so-called 'fallen angels' (Hebrew 'poison angel') of Jewish and early Christian Gnostic literature. Traditionally this was the angel who, after assuming the form of a serpent (which certainly fits the context of the present rite), offered Eve the fruit from the tree of life in the Garden of Eden (Genesis 3). The xerufimb (who guarded the tree of life) in this rite also fit the context of the Garden of Eden.

The next word, manoilb is similar to „Emmanuel” (Hebrew “God (is) with us'), the name the prophet Isaiah gave to the future Messiah. Another possible source for manoilb is a Bulgarian folksong about a builder named Manoil: „Skillful Manoil is building bridges / He builds them daily, they collapse at night / Two hundred helpers, three hundred apprentices / For weeks and months have been losing the fight" ${ }^{29}$. Manoil's construction crew decides to perform a magic ritual in order to guarantee the stability of their bridge: unfortunately, it involves the burying alive, in the bridge's foundation, of whichever wife is the first to bring her husband his lunch the following morning. Manoil tries to save his own wife Marika by instruct-

${ }^{27}$ Lj. Radenković, Simbolika sveta u narodnoj magiji Južnih Slovena, Beograd 1996, p. 258.

28 ,The devil is the evil spirit of the lower places, as a fugitive he made Sotona from the heavens as his name was Satomail, thus he became different from the angels...". Apocrypha..., p. 450. A footnote from p. 447 explains that „Satan and Sammael cannot be distinguished in Rabbinic writings".

${ }^{29}$ P. Brewster, Foundation Sacrifice Motif in Legend, Folksong, Game, and Dance, in: Walled-Up Wife: a Casebook, ed. M. Dundes, Wisconsin 1996, p. 45. 
ing her „to do many extra chores before bringing his lunch... and then not to hurry in the morning" ${ }^{30}$. Fortunately, ,the elements themselves try to come to Marika's rescue by hindering her progress" ${ }^{\prime 31}$. As she walks out to the fields, a dust storm arises, ruining her husband's lunch. After preparing another lunch for him, she again goes out to meet him, but this time a heavy rain starts to fall, quickly flooding the road. The several variants of this tragic tale „have [all] preserved the fundamental conception that it was necessary to make a human sacrifice in order that a structure might be

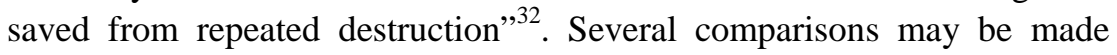
between the Manoil story and the Trebnik snakebite rite: First, the notion of Manoil as a builder/creator stands in intriguing opposition to samamoilb (who caused the downfall of Adam and Eve) as a destroyer. The human sacrifice in the Manoil folksong entails destruction as well as creation: a human life is traded for the successful creation of a bridge. Second, Manoil's lunches are ruined first by dust, then by water. In Slavic mythology, snakes have a strong association with both earth and water. „With the Slavs, the name 'snake' (zmija) is linked to the name 'earth' (zemlja)"33. After the scandal in the Garden of Eden, God tells the snake ,[U]pon your belly you shall go, and dust you shall eat all the days of your life" ${ }^{34}$. In West Slavic and Bulgarian folklore, ,the killing of a snake can cause it to rain" ${ }^{\prime 3}$. And in South Slavic folklore there are ,representations (...) of snakes as protectors of ponds" ${ }^{36}$.

The final word in the trio of names is paraklitusb, which is transparently related to Koiné Greek paráklètos 'one called, or sent for to assist another ${ }^{37}$, with the Latinized ending $-u s b$; the usual Slavic form is paraklitb. In the New Testament, the term refers to the Holy Spirit, the third portion of the Trinity. Indeed, the sequence samamoilb manoilb para-

${ }^{30}$ Ibidem.

${ }^{31}$ Ibidem.

${ }^{32}$ Ibidem, p. 46.

${ }^{33}$ Lj. Radenković, op. cit., p. 372.

${ }^{34}$ Genesis 3,14.

${ }^{35}$ A. Gura, Zmeja, in: Slavjanskie drevnosti..., p. 335.

${ }^{36}$ Ibidem.

37 Teknia New Testament Greek dictionary, <http://www.teknia.com/greek-dictionary/parakletos> [date of access: 26.9.2012]. 
klitusb appears to represent a trinity of some sort, albeit a highly distorted and non-canonical one. If this is indeed the case, the expected „Father” element has been replaced by samamoilb/Sammael ${ }^{38}$. The „Son” and „Holy Spirit" elements, though not unrecognizable as such, certainly depart from the expected forms found in either Slavic or Greek. If samamoib and manoilb in this trinity represent, respectively, a 'destroyer' and a 'creator', paraklitusb could conceivably denote a mediator between the forces of destruction and creation.

\section{Two Rites for Healing a Snakebite ${ }^{39}$}

$$
\text { [p. 93] }
$$

Ōt zmïe napiši sïe na čaše: Kagka nakagka. poi poi (ili pono pono) posor (ili posoro). pagbkana. nakararata: sïe ispisavb u čašu $i$ uli $i$ vagan i vbli vodu i ōmi imena i napoi ujadajuštago i iscěleetb. Ako li ne budetb blizu ujadeni, a ti napoi prinesbšbgo ti ōtvětb i iscělejetb ujadennü̈, i počudiši se takovu silu imati napisanïe.

Against a snake, write these [words] on a cup: Kagka nakagka, poi poi (or poio poio) posor (or posoro), pagbkana, nakararata. These having been written on the cup, pour onto a fire [?] and pour water into [the cup] and wash off the names [words] and give [it] to the victim to drink, and [the victim] will be healed. If the victim is not nearby, give [it] to drink to the one who brought you the answer ${ }^{40}$, and the victim will be healed, and you will be amazed [that] this writing has such power.

[pp. 103-104]

Ōt zmïe. Pagbkana pagka kararata poioponbtosorb. pagbkanana pagbka rarata. Se trišti na(piš)i vbi...čaše $i$ vbzbmb vodu ōmy...napoi ujadenbnago i...Ašte li něstb blizu ujadenny...prineš̌ago ōtvětb i iscělě... i počjudiši se. Takovu...napisanie se.

${ }^{38}$ The idea that these words may signify a trinity was suggested to me by Professor Daniel E. Collins in a conversation with him about this rite in early 2005.

${ }^{39}$ V. Jagić, op. cit., p. 92.

${ }^{40}$ This may denote the person who brought the victim to the performer of this rite, to be healed. 
Against a snake. Pagbkana pagka kararata poioponbtosorb. pagbkanana pagbka rarata. Write this three times on [illegible] a cup and take water, wash [illegible] give [it] to drink to the one who was bitten and [illegible] If the victim is not nearby [give it to drink to] the one who brought the answer, and [the victim] will be healed [illegible] and you will be amazed [that] this writing [has] such [illegible] ${ }^{41}$.

Jagić notes that the following table (skrižalka) appears in the middle of the text of the first rite:

\begin{tabular}{|c|c|c|c|c|}
\hline S & A & T & O & R \\
\hline A & G & E & P & O \\
\hline T & E & N & E & T \\
\hline O & P & E & D & A \\
\hline R & O & T & A & S \\
\hline
\end{tabular}

Fig. 2. Sator Square in ljčebnik

This figure represents a Sator Square - a palindromic device consisting of five words which can be read in four different directions, used since pre-Christian times as „talismanic seals (often ascribed to Solomon), ${ }^{, 42}$. Jagic's source is a slightly corrupted version of the usual SATOR AREPO TENET OPERA ROTAS. Its similarity to the magical words nakararata/kararata in Jagić's rites suggests that they too may once have been part of such a word square. The structure of this rite being very similar to that of the Trebnik rite, the presence of a Sator Square also lends credence to the possibility that sifotafarafota from the Trebnik rite may have originated as a palindromic formula.

The two rites transcribed by Jagić are obviously two slightly different versions of the same rite. Among other things, the magical words are very similar in both: Kagka nakagka. poi poi (or pono pono) posor (or posoro). pagbkana. nakararata (p. 93); Pagbkana pagka kararata poioponbtosorb.

${ }^{41}$ I am assuming that the ellipses, which are present in Jagic's transliteration, are used to by him to signify illegible text. I have indicated this in the translation, wherever the ellipses are present in Jagic.

${ }^{42}$ R. Mathieson, op. cit., p. 164. 
pagbkanana pagbka rarata (pp. 103-104). Pagbkana/pagbкa may be a corruption of the Slavic pakostb 'harm' or of poganb 'pagan, barbarous'. Another possible origin is parca (pl. parcae), one of the three Fates in Roman mythology - which brings to mind the fata element of sifotafarafota.

\section{Conclusion}

Although the healing rites I have discussed in this article appear in two very different contexts - a Church-sanctioned work for the spiritual needs of a parish, and a secular collection of healing remedies - the contents of the rites themselves are similar enough that it would not be unreasonable to posit that they share common origin. Their core structure suggests such a possibility: a series of magical words (some of which are phonologically similar, such as sifotafarafota and nakararata), followed by ritual actions involving the purification of a cup of water, concluding with the drinking of the water by either the victim or a proxy. There are also several clues suggesting that the Trebnik rite had been altered at some point prior to its being included in the text, to make it resemble a canonical rite; the strange 'trinity' of Hebrew and Greek names, and the instruction to recite the Lord's Prayer three times give the rite a superficial appearance of canonicity. Nonetheless, the only part of this rite that is truly canonical is the Lord's Prayer.

The Trebnik also directs that a proxy, and not the victim, should drink the purified water. It is possible then that the lječebnik variants reflect the original directions in this regard. The witness drinking the water was obviously the 'backup plan' in case the victim himself/herself was not in the vicinity.

Finally, it is of interest that both of the lječebnik rites conclude with the assertion that the performer of the rite ,will be amazed that this writing has such power". Such testimony of a rite's efficacy would be superfluous in a canonical work such as a trebnik, since a cleric would not have needed convincing of the inherent power of an officially-sanctioned healing rite. The power to heal would have been attributed, without question, to the direct intervention of God, not to the action of a sequence of words. 
